\title{
Ivan Jurković
}

\section{Family Ties and Written Multilingual Heritage of the Frankapani at the Dawn of the Early Modern Period}

Pregledni rad

Review article

UDK 81'246.3:929.737Frankopan>"14/15"

929.737Frankopan:930.85>(4)"14/15"

https://doi.org/10.32728/tab.17.2020.7

In the second half of the fifteenth and the first half of the sixteenth century the Frankapani of Krk, Senj, and Modruš were at the peak of their power. This family of Croatian counts was networked through marriage from the Adriatic to the Baltic Sea with Italian, Hungarian, Austrian, and German royal and aristocratic families. Their presence at the courts of their next of kin, as well as their in-laws, is therefore not surprising, whether it be the Roman Curia or the Hohenzollern Branderburger Palace in Berlin. In such a wide system of communications, the Frankapani presented themselves to the European public as a multilingual family ready to promulgate not only the written heritage honoured during the Middle Ages in Croatia (Latin and Glagolitic), but also ready to adopt, promote, and disseminate the written heritage of their spouses (Italian, German, Hungarian).*

Key words: the Frankapani of Krk, Senj, and Modruš, the German-Roman Breviary, the anti-Turkish speech Oratio pro Croatia, the translated epistles of Saint Paul Epistolae Pavli lingva Hvngarica donatae, prayer book HortuIus Animae, symbolic communication, (self)promotion, sixteenth century

In late mediaeval and early modern times, not a soul in Western Christendom questioned the legend that Pope Gregory the Great (590-604) was descended from the Frankapani (It. Frangipani, Hung. Frengepáni). The Frankapani of Krk promoted this legend as a key 
facet of their identity when presenting themselves to Europe's secuIar and ecclesiastical elites, of which they were a part. For instance, the seventeenth century saw the publication of a book on the Frankapani, one which endorsed ideas propounded by such ecclesiastical authorities as Pope Martin V (1417-31) and Pius II (1458-64), who claimed that the Counts of Krk were descended from the Frankapani, a noble family whose most notable scions were Pope Felix III (483-92) and his great-grandson, Gregory the Great. ${ }^{1}$

The popes mentioned were in a similar manner represented in a fifteen-volume heraldic collection on Italy's noble families and dignitaries of the Catholic Church. The collection, which was found in the library of Albert V, Duke of Bavaria, came into being sometime between 1550 and 1555, and was edited by the artist, inventor, and antiquarian Jacopo Strada of Mantua. The first volume, and thereby the entire collection, opens with the coats of arms of Felix III and Gregory the Great. ${ }^{2}$ The following volumes contain the coats of arms of the Frankapani of Rome, Naples, Venice, and, of course,

\footnotetext{
* The text has been prepared in conjunction with the project „Sources, Manuals and Studies for Croatian History from the Middle Ages to the End of the Long Nineteenth Century" of the Croatian Science Foundation (code: 6547), guided by research advisor Ph.D. Damir Karbić.

1 Cf. Francesco Zazzera d'Aragonia, Della famiglia Frangipani tratta della seconda parte della nobiltà dell'Italia, Naples 1617, chapter: “Della famiglia Frangipani d'Vngheria di Dalmazia e del Frivle" like such statements: Frangipanibus, de qua fuit Papa Gregorius magnus Eccl. doctor...; Faelix 3. natione Italus ... de nobilissima domo Anicia, quae postea Frangipanum appellata est.; Hi fuerunt Epiiscopi duo, Cenadiensis, \& Segniensis; \& cum his Stephanus Croatiae Comes ab origine Romanus Frangepania gente, quam sanctissimum olim Pont. Gregorium produxit...
}

2 The immensely rich Augsburg nobleman, Johann Jakob Fugger (1516-75), commissioned his friend Jacopo Strada (1507-88) to compile the said fifteen-volume heraldic collection for the Fugger library. This representative collection finally ended up in the Library of Bavarian Duke of Albert V Wittelsbach (1528-79) in whose service Fugger was. All volumes are available through the homepage of the online project BSB-Codlcon (http://codicon.digitale-sammlungen.de/start.html) by accessing the link Heraldik and then selecting the list of digitized manuscripts from Cod.icon. 266 [Katalog] to Cod.icon. 280 [Katalog]. The coats of arms of Pope Felix and Gregory the Great are located at: Cod. icon. 266 [Katalog] under the title Insignia pontificum Romanorum et cardinalium. I. Insignia a Felice III. ad Paulum IV., fol. 1r and 2r (web site accessed: October 23, 2018). 
the Frankapani of $\mathrm{Krk}^{3}$ (Fig. 1). The reputation of the aforementioned Frankapani also rested on their family ties to Gregory the Great, one of the Church Fathers. ${ }^{4}$

\section{FAMILY TIES}

The first among the Frankapani from Croatia whom we will mention is Stephen II Frankapan (Fig. 2). In the year 1446 Count Stephen II, and with him a fine company in exquisite array, came to Venice. Clad in garments embroidered with pearls of great value, he asked the Signoria whether or not he should wed the sister of the Margrave Leonello d'Este of Ferrara, the nuptials having already been agreed upon. The Doge, however, retorted that it seemed to him, for diverse reasons and considerations, unwise that the Count should take the said lady as wife, since many other desirable consorts were to be had. Stephen, having expressed his gratitude to the Signoria, continued merrily with his entourage to Ferrara, where he came on April 22 (Friday), and on Sunday, April 24, married Isotta d'Este, the celebration lasting until May 1 (Sunday) in the Great Hall opposite the Old Castle (Sala Grande de la corte verso lo Castello Vecchio). The master of ceremonies was the Margrave Gianlucido Gonzaga of Mantua, brother-in-law to Leonello d'Este. Over the course of the nuptials, the escort of Isotta's maid of honor fell dead during the

3 Cf. coats of arms of the Frankapani of Rome in: München, Alte Hofbibliothek - 129 $\mathrm{BI}$, under the title Insignia ... III. Insignia nobilium urbis Romae praecipuorum item Viterbiensium. Available through web pages in the same way with the choice of Cod.icon. 268 [Katalog], fol. 59r. For the Frankapani of Naples in München, Alte Hofbibliothek - $172 \mathrm{BI}$, under the title Insignia ... XIV. Insignia nobilium Neapolitanorum et Genuensium. The same approach access through Cod.icon. 279 [Katalog], fol. 49r. For the Frankapani of Venice and Krk in München, Alte Hofbibliothek - $194 \mathrm{BI}$, under the title Insignia ... VII. Insignia Venetorum nobilium II (A-IP) respectively Cod.icon. 272 [Katalog], fol. 161r. More detail on coats of arms of the Frankapani see in: Ivan Jurković, O grbovima u molitvenicima koje su dali tiskati 1518. u Veneciji Krsto Frankapan sa suprugom Apolonijom Lang i 1560. u Padovi Katarina Frankapan, supruga Nikole Zrinskog Sigetskog, Zbornik Odsjeka za povijesne znanosti Zavoda za povijesne i društvene znanosti HAZU, vol. 35, 2017, 61-84.

4 For a very good account of the creation of the myth about the Franakapan origins of the Counts of Krk, Senj, and Modruš, as well as Gregory the Great's ties to the Frankapani family, with detailed literature see: Luka Špoljarić, Illyrian Trojans in a Turkish Storm: Croatian Renaissance Lords and the Politics of Dynastic Origin Myths, in P. Baker - R. Kaiser - M. Priesterjahn - J. Helmarth (eds.), Portraying the Prince in the Renaissance. The Humanist Depiction of Rulers in Historiographical and Biographical Texts, ser. Transformationen der Antike, vol. 44, Berlin 2016, 121-156. On the use of the figure of Pope Gregory the Great in (self)promotion of the Frankapani of Krk see: Ivan Jurković, Sveti Grgur Veliki u Njemačko-rimskom brevijaru (1518.), na freskama u Sveticama (1541.) i u Raju duše (1560.) koje su naručili Frankapani Modruški i Ozaljski, Slovo: časopis Staroslavenskog instituta u Zagrebu, vol. 70, 2019, 137-154. 
dance, which was interpreted as a bad omen for the bride's impending married life. ${ }^{5}$ Indeed, after ten years of marriage, she suddenly died. ${ }^{6}$ Her tombstone, however, unlike her son Bernardin's, as well as those of his children and grandchildren, at least remains partially preserved ${ }^{7}$ (Fig. 3). On this occasion it is important to emphasize that by marrying Isotta Stephen gained as in-laws powerful Italian rulers - the Aragon of Naples, ${ }^{8}$ Gonzaga of Mantua, ${ }^{9}$ Malatesta of Rimini, ${ }^{10}$ and Montefeltro of Urbino ${ }^{11}$ (Fig. 4).

5 Cf. Giuseppe Pardi (ed.), Bernardino Zambotti, Diario ferrarese dall'anno 1409 sino al 1502, in Rerum Italicarum Scriptores, tom. XXIV, part. VII, fasc. 5-6, Bologna 1934, p. 29, lin. 24-29 and p. 30, lin. 1-2. The following Croatian historians have also written about this marriage: Vjekoslav Klaić, Krčki knezovi Frankapani. Knjiga prva. Od najstarijih vremena do gubitka otoka Krka (od god. 1118. do god. 1480.), Zagreb 1901, p. 230. The wedding and marriage are also mentioned by other researchers of the history of the d'Este family, such as James Dennistoun, Memoirs of the Dukes of Urbino, vol. 1 (of 3), new ed. with notes by Edward Hutton, London-New York 1909, p. 55; Thomas Tuohy, Herculean Ferrara: Ercole D'Este (1471-1505) and the Invention of a Ducal Capital, Cambridge 2002, p. 59; Lewis Lockwood, Music in Renaissance Ferrara 1400-1505: The Creation of a Musical Center in the Fifteenth Century, New York-Oxford 2009, 119-120; Beatrice Saletti, La successione di Leonello d'Este e altri studi sul Quattrocento ferrarese, Collana: Studi e progetti, Padua 2015, 71-72.

6 Vjekoslav Klaić, op. cit., p. 241-242.

7 For Isotta's tombstone see: Zorislav Horvat, Sačuvani nadgrobni spomenici nekih Senjana i osoba značajnih za povijest Senja - u Senju i drugdje, Senjski zbornik, sv. 29, 2002, 55-60. Due to the devastation of the graves and memorials of the Frankapani family, there are also different interpretations of the attribution of sarcophagi and tombstones to other individual members of this family, see: Vjekoslav Klaić, $o p$. cit. p. 261, fig. 35; Zorislav Horvat, Pregled sačuvanih nadgrobnih ploča krčkih knezova Frankopana, Senjski zbornik, vol. 32, 2005, 25-56; Predrag Marković, Mramorni reljefi venecijanske radionice Bon u Senju i krčki knezovi Frankopani, Radovi Instituta povijesti umjetnosti, vol. 30, 2006, 9-28 and in literature cited in these works.

8 The second wife of Isotta's brother Leonello (1441-50) was Mary of Naples, daughter of King Alfonso of Aragon, and the wife of her other brother Ercole I (1471-1505) was Eleanor of Naples, daughter of King Ferrante I of Aragon; Thomas Tuohy, op. cit., p. XXVI.

9 The first wife of Isotta's brother Leonello was Margherita Gonzaga, who was sister of the Margraves Carlo and Gianlucido of Mantua. Moreover, Isotta's sister Lucia was also the first wife of the aforementioned Carlo Gonzaga; Thomas Tuohy, ibid.

10 Isotta's sister Ginevra was the first wife of Sigismondo Pandolfo Malatesta of Rimini (1432-68); Thomas Tuohy, ibid. About Ginevra's fate in that marriage more in: Anthony F. D'Elia, Pagan Virtue in a Christian World: Sigismondo Malatesta and the Italian Renaissance, Cambridge 2016, 186-188.

11 Prior to marrying Stephen, Isotta was engaged to Oddantonio da Montefeltro, but he was killed in a conspiracy (1444) before the wedding could take place (see: James Dennistoun, op. cit., 55-57). The Montefeltro family at that time, however, had other matrimonial ties with the Gonzaga family, thus Isotta and Stephen maintained contact with them. 
After Isotta's death, however, Stephen went a step further. He arranged for their son Bernardin to marry Princess Luisa Marzano of Aragon and thereby established new family ties. ${ }^{12}$ Luisa had five sisters, all of them married. ${ }^{13}$ Bernardin could thus count among his brothers-in-law: Antonio Todeschini-Piccolomini (Duke of Amalfi, a nephew of Pope Pius II and brother of Pope Pius III), ${ }^{14}$ Vlatko Kosača (Duke of Herzegovina), ${ }^{15}$ Costanzo I Sforza (Lord of Pesaro and Gradara), ${ }^{16}$ Leonardo III Tocco (Duke of Lefkada and ruler of Epirus), ${ }^{17}$ and Antonio Basso della Rovere (Margrave of Cisterna, a nephew

\footnotetext{
12 Bernardin became engaged to Luisa while he was in Naples as a member of a splendid entourage that King Matthias Corvinus had sent to escort his fiancée and Princess Beatrice of Aragon to Buda. Because they were fourth cousins, however, Luisa and Bernardin had to ask for a papal approval before the wedding. The journey and stay in Naples, as well as the papal dispensation that Bernardin had to obtain, were described in Szabolcs de Vajay, Un ambassadeur bien choisi: Bernardinus de Frangipanus et sa mission à Naples, en 1476, in B. Nagy - M. Sebók (eds.), The Man of Many Devices, Who Wandered Full Many Ways: Festschrift in Honor of János M. Bak, Budapest 1999, 550-557.
}

13 Rinaldo Fulin et al. (eds.), I diarii di Marino Sanuto, vol. 29, Venice 1890, p. 544; Vjekoslav Klaić, op. cit., 267-268. All of them betrayed King Ferrante - conducting the policy of dynastic relations with the families who entered the Anti-Ottoman Alliance. They were the daughters of Ferrante's sister Eleonor and Duke Marino Marzano. Marino participated in the Conspiracy of the Barons and was in custody until his death - his possessions were confiscated.

14 The first wife of Antonio was Mary, daughter of King Ferrante, with whom he had two daughters. His second wife was the Luisa's eldest sister, also Mary. With her he had four sons and three daughters; Rinaldo Fulin et al. (eds.), op. cit., p. 544. For the rise of the Piccolomini family in the second half of the fifteenth century see Ilaria Puglia, I Piccolomini d'Aragona duchi di Amalfi (1461-1610). Storia di un patrimonio nobiliare, ser. Ricerche storiche 9, Naples 2005.

15 Margherita, Luisa's elder sister, was the second wife of Vlatko. For the destiny of the refugee and the generations of the Kosača family that finally moved to Venice, see Rinaldo Fulin et al. (eds.), op. cit., p. 544; Lovorka Čoralić, Ogranak humske velikaške obitelji Kosača u Mlecima: tragom oporučnih spisa (16.-17. stoljeće), Zbornik Odsjeka za povijesne znanosti Zavoda za povijesne i društvene znanosti HAZU, vol. 35, 2017, 145-155.

16 Rinaldo Fulin et al. (eds.), op. cit., p. 544. A very detailed biography of Costanzo Sforza in Francesco Ambrogiani, Vita di Costanzo Sforza (1447-1483), Pesaro [2003]. Translation of the manuscript about the wedding of Camilla, the sister of Luisa, and Costanzo: Jane Bridgenan (ed.), A Renaissance Wedding: the Celebrations at Pesaro for the Marriage of Costanzo Sforza \& Camilla Marzano d'Aragona, 26-30 May 1475, London-Turnhout 2013. That marriage produced no children.

17 Rinaldo Fulin et al. (eds.), op. cit., p. 544; Kenneth M. Setton, The Papacy and the Levant, 1204-1571. The fifteenth century, Philadelphia 1978, p. 341. Luisa's younger sister, Francesca, was married to Leonardo. The best study on the rise and struggles with the Ottomans in the Epirus area and finally on the refugee fate of the Tocco family in the Kingdom of Naples is Nada Zečević, The Tocco of the Greek Realm: Nobility, Power and Migration in Latin Greece (14th - 15th centuries), Beograd-Istočno Sarajevo 2014 - Leonardo's marriage ties on p. 185. 
of Pope Sixtus IV, and first cousin of Pope Julius II) ${ }^{18}$ (Fig. 5). In a political sense, however, Stephen and his son Bernardin actually entered an anti-Turkish alliance formed by Ferrante of Aragon and Pope Sixtus IV, cemented by a series of dynastic marriages ${ }^{19}$ (Fig. 4). The alliance was immortalized in a painting commissioned by Ferrante I and Sixtus IV, painted by the Venetian renaissance artist Lazzaro Bastiani. This painting, originally a gift to the Marian shrine of Basillica della Santa Casa in Loreto, is nowadays kept at the Monastery of St. Francis of Assisi in Zadar, and is therefore relatively unknown ${ }^{20}$ (Fig. 6). Be it as it may, it was these dynastic ties that enabled Bernardin Frankapan to enter the ranks of Europe's powerful ruling families, and to marry off his daughter Beatrice to John, son of Matthias Corvinus (Fig. 7). ${ }^{21}$

Thanks to a shrewd dynastic strategy, Bernardin set up an extensive network of political, ecclesiastical and economic ties in all European centres of power. His children formed alliances by marrying members of various noble families from the Kingdoms of Hungary and Croatia, as well as those from the Holy Roman Empire. His eldest son, Matthias, married Sophia, who was the widow of Andrew Henning of Susedgrad, and who hailed from the respectable Hungarian family of Thuz de Lak. ${ }^{22}$ Christopher's wife Apollonia was the sister of Matthäus Lang von Wellenburg, Archbishop of Salzburg and Chancellor to Emperor Maximillian I, ${ }^{23}$ and Mary, Ferenat's spouse, was daughter of the

18 Luisa's youngest sister, Caterina, was married to Antonio; Rinaldo Fulin et al. (eds.), op. cit., p. 544. However, Antonio died suddenly the following year, so that marriage also remained childless. On the rise of the della Rovere family and their patronage role in the history of art, see Ian F. Verstegen (ed.), Patronage and Dynasty: the Rise of the Della Rovere in Renaissance Italy, ser. Sixteenth Century Essays \& Studies, vol. 77, Kirksville 2007 - genealogy on p. 201.

19 A description of the intricate relations of alliance and hostility between the main actors of the anti-Ottoman Alliance, Pope Sixtus IV and King Ferrante, see in Kenneth M. Setton, op. cit., 325-345 and 364-373.

20 Cf. Ivana Prijatelj Pavičić, Kroz Marijin Ružičnjak: Zapadna marijanska ikonografija u dalmatinskome slikarstvu od 14. do 18. st., Split 1998, 68-76.

21 Ivan Kukuljević Sakcinski, Beatrica Frankopan i njezin rod, Zagreb 1885; Szabolcs de Vajay, op. cit., p. 553, no. 25 and p. 557, fig. 2; Ivan Jurković, O grbovima..., 78-83.

22 Szabolcs de Vajay, op. cit., p. 553, no. 25.

23 Johann Sallaberger, Kardinal Matthäus Lang von Wellenburg (1468 - 1540) Salzburg 1997, p. 36; Marija Šercer, Žene Frankopanke, Modruški zbornik, vol. 4-5, 2011, 54-6o. 
Despot John Branković. ${ }^{24}$ After the tragic demise of her husband John Corvinus and their two young children, Bernardin's daughter Beatrice married George, Margrave of Brandenburg-Ansbach, from the House of Hohenzollern. ${ }^{25}$ Another daughter, Mary Magdalen, was betrothed to Matthias Pongrácz de Dengeleg, a Hungarian nobleman. However, what became of her remains unclear. ${ }^{26}$ Isotta's husbands also were Hungarian aristocrats. Her first husband, Ladislaus, was the son of Ladislaus of Egerváry, the famed Croatian ban/viceroy, her second husband was Stephen Perényi de Nagyida, and the third one was Caspar Serédy. ${ }^{27}$ In choosing an Aragon bride for his son, Stephen gained powerful allies in the Italian peninsula. Bernardin followed in his father's footsteps strategy-wise: by marrying off his children to scions of Central European noble families, he found allies willing to help with the ongoing Ottoman wars (Fig. 4).

To summarize, in the second half of the fifteenth century and the first half of the sixteenth century the Frankapani of Krk, Senj, and Modruš were at the peak of their power. This family of Croatian counts was networked through marriage from the Adriatic to the Baltic Sea with Italian, Hungarian, Austrian, and German royal and aristocratic families. Their presence in the courts of their next of kin, as well as their in-laws, is therefore not surprising, whether it be the Roman Curia or the Hohenzollern Branderburger Palace in Berlin.

\section{WRITTEN MULTILINGUAL HERITAGE}

In such an elaborate system of communication, the Frankapani presented themselves to the European public as a multilingual family ready to promulgate not only the written heritage nurtured during the Middle Ages in Croatia (Latin and Glagolitic), but also ready to adopt, promote, and disseminate the written heritage of their spou-

24 Matija Mesić, Pleme Berislavića, Slavonski Brod 2000, p. 48; Szabolcs de Vajay, op. cit., p. 553, no. 25.

25 Ivan Kukuljević Sakcinski, Beatrica Frankopan...; Adolf Bayer, Markgraf Georg und Beatrix von Frangepan: Georg des Frommen Jugend und erste Ehe, Ancbach 1934. - offprint from: Neujahrsblätter - Gesellschaft für Fränkische Geschichte, vol. 19, 1906, 1-36; Marija Šercer, Žene Frankopanke..., 46-50. For the preserved portraits of Beatrice and how they became a template for the display of St. Hemma of Gurk see: Sanja Cvetnić, Dva portreta Beatrice Frankapan (?): rod i red, Radovi Instituta za povijest umjetnosti, vol. 42, 2018, 85-94.

26 Marija Šercer, Žene Frankopanke..., 45-46. 
ses (Italian, German, Hungarian). The following examples attest to this statement:

1. the Roman breviary translated into the German language by Christopher Frankapan and his wife Apollonia Lang printed in 1518 in Venice,

2. the anti-Turkish speech in Latin delivered by Christopher's father, Bernardin, before the German assembly in Nuremberg and printed in 1522 for the occasion,

3. the translated epistles of Saint Paul, from Latin to Hungarian, donated by Catherine Frankapan married to Gabriel (Gábor) Perényi, printed in Krakow in 1533, and

4. the first Croatian-language breviary written in the Latin script, rather than in the Glagolitic, commissioned by Catherine Frankapan married to Nicholas Zrinski, published in 1560 in Padua.

\section{1) The German-Roman Breviary}

The German-Roman Breviary was first printed by Christopher Frankapan and his wife Apollonia Lang of Wellenburg during his incarceration in Venice (1514-19). The couple edited the volume in collaboration with Jacob Wyg, a German monk. ${ }^{28}$ Although this year marks the Breviary's 500th anniversary, ${ }^{29}$ and notwithstanding the fact that it was referenced numerous times over the past five centuries, every generation of historians has experienced trouble finding it, all thanks to its title. Namely, earlier manuals, as well as encyclopaedias, register it as the Petbuch die Syben Zeit von Latein in Deutsch gemacht. ${ }^{30}$ It was Matija Mesić who in 1870 first pointed

28 Das deutsch-römisch Brevier..., ed. Gregorius de Gregoriis, Venice 1518.

29 The Breviary was printed at „... letsten tag octobris desß xv. hunderten vnd xviij. iars.” - October 31, 1518; ibid., p. A2v; cf. Ivan Jurković, Njemačko-rimski brevijar 1518. (500. obljetnica), Istarska danica, year 2018, Pazin 2017, 72-75. Students of the Department of Art History under the guidance of Full Prof. Sanja Cvetnić made an exhibition in the auditorium of the Library of the Faculty of Humanities and Social Sciences, University of Zagreb under the title Deutsch-römisches Brevier: 500 years - 400 copies - 1 anniversary (January 16-28, 2019).

30 Cf. Georg Wolfgang Panzers, Annalen der ältern deutschen Litteratur..., Nürnberg 1788, 411-412; Ignaz Franz von Mosel, Geschichte der Kaiserl. Königl. Hofbibliothek zu Wien, Vienna 1835, p. 338; Šime Ljubić, Natpis Krsta Frankopana i njegove žene Apolonije, u Mletcih, Viestnik Hrvatskoga arkeologičkoga družtva II/1, 1880, 61-62; Petar Strčić, Frankapan, Krsto I. Brinjski, in Hrvatski biografski leksikon, vol. 4, Zagreb 1998, p. 414. 
to the existence of Christopher's breviary. ${ }^{31}$ Wider audiences came to know of it at the turn of the century, following the publication of Der Ring des Frangipani, a work of historical fiction penned by the German art historian Henry Thode. ${ }^{32}$ The success of the novel prompted a series of research and newspaper articles on the Breviary. ${ }^{33}$ Those articles, however, only went so far as to describe the Breviary. Hence, the Breviary has yet to be subjected to critical analysis.

The Breviary contains a number of prints - a calendar adorned with allegorical representations of the months of the year, the coats of arms of the Frankapans and Langs, a series of medallions, each embellished with innumerable initials, and, finally, minuscule woodcut depictions of various symbolical figures. However, what stands out for its extraordinary beauty is a set of ten large prints, the first and last of which are identical and depict ,the Coronation of the Virgin", with Christopher and Apollonia on their knees, praying opposite one another (Fig. 8). The remaining eight prints portray the most significant events of the New Testament, from the „Annunciation” to the „Meeting at the Golden Gate”. Each of these prints is framed by a set of medallions, occurring periodically in different combinations. The texts in the Breviary come in two colors, black and red, with certain, emphasized parts printed in bold letters.

The Breviary was printed in what was then a large number of copies - 400. Until recently, Croatian historians were convinced that only two copies had survived the tumultuous times of conflict between the Holy Roman Empire's Protestants and Catholics. ${ }^{34}$ It

31 Matija Mesić, Krsto Frankapan u tudjini, Rad Jugoslavenske akademije znanosti i umjetnosti, vol. 13, 1870, 77-79.

32 Henry Thode, Der Ring des Frangipani: ein Erlebniss, Frankfurt am Main 1895. The book was also printed in English (Frangipani's Ring. An Event in the Life of Henry Thode, London 1900 and 1904) and finally in Croatian: Frankopanov prsten: doživljaj, Zagreb 1944 and 1992.

33 Cf. e.g. Camilla Lucerna, Das Frankopani - Brevier, Der Morgen, Jg. 3, Nr. 687, Zagreb 1925, p. 12; Nikola Žic, Brevir Krsta Frankopana, Obzor 74/224, Zagreb 1933, 2-3.; Marija Šercer, Žene Frankopanke..., 57-60; Milan Kruhek, Modruški Bernardin i Krsto Frankopan: mačem i govorom za Hrvatsku, Modruški zbornik, Posebna izdanja, vol. 3, Modruš 2016, 130-133; Ivan Jurković, Njemačko-rimski brevijar..., 72-75.

34 In spite of the fact that in 1925 eight copies of the Breviary were known to exist (in Austria, Germany, Italy, and Hungary; cf. Camilla Lucerna, op. cit., p. 12), contemporary Croatian literature still claimed that only two remained, namely those in Heidelberg and Budapest; cf. Ines Srdoč-Konestra - Saša Potočnjak (eds.), Putovima Frankopana, Rijeka 2018, 328-329 (in the chapter of Saša Potočnjak with bibliographic references to such claims). 
has transpired, however, that Christopher and Apollonia's breviary is to be found, though under different names, worldwide. Namely, numerous reputable libraries (such as those in Australia, Austria, Croatia, Germany, Hungary, Italy, the Netherlands, Russia, the US and the UK, to name but a few) house the Breviary as a key achievement in early translation into German. ${ }^{35}$

\section{2) Oratio pro Croatia}

The anti-Turkish speech Oratio pro Croatia in Latin delivered before the German assembly in Nuremberg by Christopher's father, Bernardin, was printed in 1522 for the occasion. ${ }^{36}$

The surviving copies of Bernardin Frankapan's Oratio pro Croatia are an important testimony of Croatian history. Many Croatian historians were aware of this fact. There is hardly a synthesis or monography on late mediaeval/early modern Croatian history which does not (at least)

35 Samples of the Breviary are kept in Australia (Melbourne, State Library Victoria Sticht Collection, sign. 347[2]), Austria (Vienna, Österreichische Nationalbibliothek, sign. 22E23), Croatia (Zagreb, Nacionalna i sveučilišna knjižnica, lok. Zbirka rijetkosti, sign. RIIF$8^{\circ}$-1832), Germany (Augsburg, Staats- und Stadtbibliothek, sign. 4 Th Lt K 17; Augsburg, Universitätsbibliothek Augsburg, sign. 02/XIII.10.4.64; Eichstätt - Ingolstadt, Katolische Universität, Universitätsbibliothek, sign. 04/1 AÖ 15; Freising, Dombbiliothek Freising, sign. M/086 00224 / M; Munich, Stadtarchiv München / Historischer Verein von Oberbayern, sign. 01/Ver. Bibl. 1144 / 01 03/Rara Remota Frühdrucke; Munich, Universitätsbibliothek der LMU München, sign. 0014/W 4 Liturg. 204; Munich, Bayerische Staatsbibliothek: sign. 4 Liturg. 123 a; Res/4 Liturg. 123), Hungary (Budapest, Országos Széchényi Könyvtár, sign. App. H. 131), Italy (Gardone Riviera, Biblioteca della Fondazione I/ Vittoriale degli Italiani, sign. ZTN 10; Rome, Biblioteca apostolica vaticana, sign. Stamp. Ross.5041; Trento, Biblioteca Diocesana Vigilianum, sign. LO 125), Netherlands (Den Haag, Koninklijke Bibliotheek, sign. KW 233 F 25), UK (London, The British Library in the collection General Reference Collection na dvije lok. C.25.k.3. and C.35.h.3.), and USA (Cambridge, Harvard Library, sign. Houghton Typ 525 18.262; Chicago, Newberry Library, sign. VALUT Wing ZP 535.G866; New York, New York Public Library, sign. Spencer Coll. Ital. 1518). In Berlin, a sample (sign: 4 „Dq 11356) was kept in the Staatsbibliothek zu Berlin, but it was „sheltered” at the end of the Second World War to the Russian State Library (Российская государственная библиотека) in Moscow. The Breviary is available through the website of two libraries: Österreichische Nationalbibliothek in Vienna (http://digital.onb.ac.at/OnbViewer/ viewer.faces?doc=ABO_\%2BZ221484602) and Bayerische Staatsbibliothek in Munich (http://reader.digitale-sammlungen.de/de/fs1/object/display/bsb10164199_00001.html).

36 Bernardinus de Frangepanibus, Oratio pro Croatia. Nürenbergae in Senatu Principum Germaniae habita [Nürnberg: Friedrich Peypus], 1522. This speech is also available through the website of: Bayerische Staatsbibliothek in Munich; sign: Res/4 Eur. 332,9 (https://books.google.hr/books?id=AktTAAAAcAAJ\&printsec=frontcover\&source=gbs_ViewAPI\&redir_esc=y\#v=onepage\&q\&f=false) and Österreichische Nationalbibliothek in Vienna; sign: 43.S.29 ALT PRUNK (http://digital.onb.ac.at/OnbViewer/ viewer.faces?doc=ABO_\%2BZ103516402). 
mention this speech. ${ }^{37}$ However, it was only recently - eight years ago, to be exact - that Oratio pro Croatia was first presented to Croatian audiences in its entirety. ${ }^{38}$

The speech was printed in Nuremberg by the printing house of a certain Friedrich Peypus (Fig. 9). ${ }^{39}$ It consists of four Antiturcica texts. The first one, an epistle addressed to Pope Hadrian VI, serves as an introduction to the remaining three, which are all speeches delivered before the Imperial Diet of the Holy Roman Empire. Over the course of his politico-diplomatic mission, Bernardin had his speech printed in order to distribute it as a kind of anti-Ottoman pamphlet. Two facts might serve as proof of his doing so: first, the scarcity of visuals in the pamphlet, which allowed for the printing of a greater number of copies, and secondly, the numerous surviving copies of the speech throughout Central and Western Europe. ${ }^{40}$

The text is important not just as a historical and literary artefact, but also as a linguistic testimony. It proves that a Croatian nobleman, hailing from the ever-changing frontier between the (Ottoman) East and the (Christian) West, could master Latin, one of the pillars of contemporary culture, and use it as a means of diplomacy. ${ }^{41}$

37 Cf. e.g. Tadija Smičiklas, Poviest hrvatska, Zagreb 1882, 707-708; Vjekoslav Klaić, Povijest Hrvata, bk. 4, Zagreb 1973, 358-36o; Vedran Gligo, Govori protiv Turaka - Orationes contra Turcas, ser. Humanisti, bk. 7, Split 1983, 35-36; Matija Mesić, Hrvati na izmaku srednjega vijeka, Bibliotheca Croatica - Slavonica, Sirmiensia et Baranyensia, Pretisci, bk. 1, Slavonski Brod 1996, 267-268 and 273-274; Tomislav Raukar, Hrvatsko srednjovjekovlje: Prostor, ljudi, ideje, Zagreb 1997, 108 and 491-492; Ines Srdoč-Konestra - Saša Potočnjak (eds.), Putovima Frankopana..., 65-68 (in the chapter of Maja Ćutić Gorup).

38 Bernardin Frankapan Modruški, Oratio pro Croatia - Govor za Hrvatsku (1522.), Modruški zbornik: Posebna izdanja, bk. 1, I. Jurković - V. Moretti (eds.), Zagreb 2010.

39 Syrmian Bishop Ladislas (László) Macedóniai printed his speech in the same printing house (cf. Katalin S. Németh, Ungarische Drucke und Hungarica 1480-1720, Teil 1-3, Munich-New York-London-Paris 1993, p. 917). He delivered the speech before the German assembly as the envoy of the Hungarian king Louis II. Jagiellon. Much as Bernardin sought help for Croatia, so did Ladislas for Hungary; cf. István K. Horváth (ed.), Orationes Ladislai de Macedonia, Acta Universitatis de Attila József nominatae, Acta antiqua et archaeologica, tom. VII, Szeged 1964.

40 Cf. Ivan Jurković, Diplomatska aktivnost hrvatskoga plemstva u vrijeme turskoga pritiska na Hrvatsku, in M. Andrlić - M. Valentić (eds.), Hrvatska srednjovjekovna diplomacija, Zbornik Diplomatske akademije, vol. 2, Zagreb 1999, 243-256. Lists of institutions that preserve copies or transcriptions of Oratio pro Croatia see in Bernardin Frankapan Modruški, op. cit., 126-129.

41 Cf. Violeta Moretti, Oratio pro Croatia Bernardina Frankapana, Modruški zbornik, vol. 3, 2009, 165-186; Bernardin Frankapan Modruški, op. cit., 85-10o and 123-124. 


\section{3) Epistolae Pavli lingva Hvngarica donatae. Az Zenth Paal leveley magyar nyelven}

„Take into your hands Paul, who is not Jewish any more, nor is he Greek, but he is Hungarian" - this statement appears as the first sentence in the preface of $A z$ Zenth Paal leveley magyar nyelven (Epistles of Saint Paul in the Hungarian language), the first book to be printed in Hungarian in its entirety, as Pál Ács first claimed in his text eight years ago..$^{42}$ The book was printed in Krakow in 1533, and donated by Catherine Frankapan, widow of Gabriel (Gábor) Perényi (Fig. 10). The epistles of Saint Paul were translated from Latin into Hungarian by Benedek Komjáti. ${ }^{43}$ It is important to note that this was an Erasmian translation of Saint Paul's letters and that the Latin-language dedication to Hungarian readers was written by the printer and publisher Hieronymus Vietor. ${ }^{44}$ Vietor was born in Silesia (Lubomierz) and was active in Vienna and Krakow. Famous for the quality and quantity of his prints, he is considered to have been one of the most important early book printers in Poland, as because he was the first to regularly print in Polish. As a humanist, he was open to new ideas, and not afraid to publish works about novelties, including new religious ideas, although he himself was never openly Protestant. Very soon after the printing of Paul's epistles, in 1536 Vietor came into conflict with the Catholic Church. ${ }^{45}$

Catherine, a countess who originated from Croatia, ${ }^{46}$ helped financially to print the first book in Hungarian. But what a book! According to researchers, it was one of the most finely made books of its time. Thus,

42 Pál Ács, The reception of Erasmianism in Hungary and the context of the Erasmian program: the 'cultural patriotism' of Benedek Komjáti, in B. Trencsényi - M. Zászkaliczky (eds.), Whose Love of Which Country?, Leiden-Boston 2010, p. 75.

43 The title cover with several illustrations and basic bibliographic data about $A z$ Zenth Paal leveley magyar nyelven can be found in Károly Horányi - Edit Krähling (eds.), Calliotheca. Gems from the Library of the Hungarian Academy of Sciences, Budapest 2017, p. 277. For more information and content descriptions, see Gedeon Borsa et al. (eds.), Régi Magyarországi Nyomtatványok, köt. 1, 1473-1600, Budapest 1971, no. 13.

44 Cf. Pál Ács, The reception of Erasmianism in Hungary..., 85-87 and literature cited in this article.

45 Fascimile edition of Az Zenth Paal leveley magyar nyelven published by Magyar Tudományos Akadémia [Hungarian Academy of Sciences] in 1883 with Áron Szilády's commentary. An overview of Vietor's political and religious activity with reference to relevant literature can be found in Alfred Świerk, Hieronymus Vietor (Wietor) - ein Pionier des polnischen Buchdrucks im 16. Jahrhundert, Gutenberg-Jahrbuch, Jahr. 51, 1976, 194-199. 46 Her great-grandfather John was the brother of Stephen II (see fig. 4). 
Vietor printed an eulogy to her in Latin at the end of the book saying: „Your court is like a school of piety of all Christianity ... Above all, your glory shines bright, especially among Panonians; for you are to them precisely what your family name says - a Frangepanibus. Namely, you are now breaking, giving, and sharing bread to those who are hungry, that bread of life, which comes down from Heaven..." ${ }^{37}$

\section{4) Hortulus Animae (Raj duše)}

Up until recently, it was believed that the book kept at the Franciscan monastery in Trsat was the only remaining copy of Catherine's prayer book, Hortulus Animae (Raj duše), which once belonged to the confraternity of the Blessed Virgin Mary. ${ }^{48}$ It is precisely for this reason that a facsimile, accompanied by an introduction and edited by Franjo $\mathrm{E}$. Hoško, Milan Moguš, and Josip Vončina, was published. ${ }^{49}$ In describing the Hortulus Animae, Moguš and Vončina singled out the prayers addressed to St. Augustine, for they rightly observed that in those prayers Catherine beseeched health. They therefore concluded that Catherine was, at the time, „fatally ill” and ,awaiting the fast-approaching hour of her death", which prompted her to compile this prayer book with her confessor Nicholas Dešić..$^{50}$

The language of the prayer book is Croatian, but what sets it apart from other such writings is the fact that it was printed in the Latin script (whereas its predecessors had been printed in the Glagolitic script). The book was printed in Padua by the Croatian printer Gratiousus Perchacinus (Fig. 11). ${ }^{51}$ It is important to mention the fact that the Hortulus Animae contains two prayers composed by Gregory the

47 Cf. Pál Ács, The reception of Erasmianism in Hungary..., 85-86; Marija Šercer, Žene Frankopanke..., 60-62; Ines Srdoč-Konestra - Saša Potočnjak (eds.), Putovima Frankopana..., p. 329 (in the chapter of Saša Potočnjak).

48 Nicolaus Dessich (=Nikola Dešić), Hortv/vs Animae [Stoye Rechi Ray Dusse]..., ed. by Gratiosus Perchacinus (=Gracije Prkačin), Padua 1560. In addition to the Franciscan monastery in Trsat, a copy of this prayer book can also be found in Munich - Bayerische Staatsbibliothek, sign: Rar. 1889 - and is available on the website (http://reader.digitale-sammlungen.de/de/fs1/object/display/bsb10860380_oooo1.html).

49 Nikola Dešić, Raj duše, ed. by F. E. Hoško - M. Moguš - J. Vončina, Rijeka 1995.

50 Milan Moguš - Josip Vončina - Franjo Emanuel Hoško, Raj Duše s motrišta našega vremena, as a separate study of fasc. repr. of Nikola Dešić, Raj duše, ed. by F. E. Hoško - M. Moguš - J. Vončina, Rijeka 1995, 40-41.

51 Ines Srdoč-Konestra - Saša Potočnjak (eds.), Putovima Frankopana..., 329-330 (in the chapter by Saša Potočnjak) and 359-361 (in the chapter by Diana Stolac). 
Great. Those prayers can be found preceding the last chapter, which contains the „Holy Masses of the Blessed Virgin Mary” in Latin. The title of the prayers is located in the header of the page, written in simple, red letters: „Mollitua S. Gargura”, which translates to „The Prayer of St. Gregory". The Hortulus Animae ends in St. Gregory's prayers, and in Croatian at that, which signals the wish of its editors, Catherine Frankapan and Nicholas Dešić, to „situate” it in an appropriate and memorable place within the book. ${ }^{52}$ And why not? Was Catherine not descended from the same family as Gregory the Great?

\section{To summarize...}

Owing to familial ties, as well the heritage of the land the Frankapani hailed from, they, together with their spouses, promulgated everything encompassed by the term „diversity”, i.e. one can infer that they did not focus exclusively on their local identity. This diversity, itself a reflection of the unity of sixteenth century Northern-Adriatic cultures, can be observed in the fact that the aforementioned books were, in the case of Christopher:

- commissioned by a Croat and his German wife,

- printed in Venice by an Italian publisher, and

- translated from Latin into German;

in the case of Bernardin:

- commissioned by a Croat,

- printed in Nuremberg by a German publisher, and

- written in Latin;

in the case of Catherine:

- commissioned by a Croatian lady,

- printed in Krakow by a Polish publisher, and

- translated from Latin into Hungarian;

in the case of Catherine:

- commissioned by a Croatian lady,

52 Ivan Jurković, Grgur Veliki..., 141-143 and 153. 
- printed in Padua by a Croatian publisher, and

- printed in the Latin, rather than in the Glagolitic, script.

Their worldview, identity, mentality, spirituality and, above all, love thus remained bound within the covers of the German-Roman Breviary, Oratio pro Croatia, Az Zenth Paal leveley magyar nyelven, and Hortulus Animae (Raj duše)! ${ }^{53}$ What more can we ask of in this Year of European culture, as proclaimed by the European Parliament? ${ }^{54}$

\section{BIBLIOGRAPHY}

\section{AMBROGIANI 2003}

Francesco Ambrogiani, Vita di Costanzo Sforza (1447-1483), Pesaro [2003].

\section{ÁCS 2010}

Pál Ács, The reception of Erasmianism in Hungary and the context of the Erasmian program: the 'cultural patriotism' of Benedek Komjáti, in B. Trencsényi - M. Zászkaliczky (eds.), Whose Love of Which Country?, Leiden-Boston 2010, 75-90.

BAYER 1934

Adolf Bayer, Markgraf Georg und Beatrix von Frangepan: Georg des Frommen Jugend und erste Ehe, Ancbach 1934. - offprint from: Neujahrsblätter - Gesellschaft für Fränkische Geschichte, vol. 19, 1906, 1-36.

\section{BORSA 1971}

Gedeon Borsa et al. (eds.), Régi Magyarországi Nyomtatványok, köt. 1, 1473-1600 [Repertory of early Hungarian printed books, vol. 1, 14731600], Budapest 1971.

\section{BRIDGENAN 2013}

Jane Bridgenan (ed.), A Renaissance Wedding: the Celebrations at Pesaro for the Marriage of Costanzo Sforza \& Camilla Marzano d'Aragona, 26-30 May 1475, London - Turnhout 2013.

\section{CVETNIĆ 2018}

Sanja Cvetnić, Dva portreta Beatrice Frankapan (?): rod i red [Two Portraits of Beatrice Frankapan (?): the Family and the Order], Radovi Instituta za povijest umjetnosti, vol. 42, 2018, 85-94.

53 Ivan Jurković, Jedinstvo kultura sjevernog Jadrana, Jurina i Franina 2019: istarski kalendar, bk. 65, 2018, 48-49.

54 The home page of the project European Year of Cultural Heritage 2018. Our heritage: where the past meets the future was started by the European Commission, the European Parliament, and the Council of the European Union is https://europa.eu/ cultural-heritage/european-year-cultural-heritage_en. 


\section{ČORALIĆ 2017}

Lovorka Čoralić, Ogranak humske velikaške obitelji Kosača u Mlecima: tragom oporučnih spisa (16.-17. stoljeće) [A Branch of the Aristocratic Family Kosača of Hum in Venice: Tracing Testamentary Documents (the Sixteenth and Seventeenth Centuries)], Zbornik Odsjeka za povijesne znanosti Zavoda za povijesne i društvene znanosti HAZU, vol. 35, 2017, 145-155.

D'ELIA 2016

Anthony F.D'Elia, Pagan Virtue in a Christian World: Sigismondo Malatesta and the Italian Renaissance, Cambridge 2016.

DENNISTOUN 1909

James Dennistoun, Memoirs of the Dukes of Urbino, vol. 1 (of 3), new ed. with notes by Edward Hutton, London-New York 1909.

DESSICH 1560

Nicolaus Dessich, Hortvlvs Animae [Stoye Rechi Ray Dusse]..., ed. by Gratiosus Perchacinus, Padua 1560.

DEŠIĆ 1995

Nikola Dešić, Raj duše, ed. by F. E. Hoško - M. Moguš - J. Vončina, Rijeka 1995.

FRANGEPANIBUS 1522

Bernardinus de Frangepanibus, Oratio pro Croatia. Nürenbergae in Senatu Principum Germaniae habita [Nürnberg: Friedrich Peypus], 1522.

FRANKAPAN MODRUŠKI 2010

Bernardin Frankapan Modruški, Oratio pro Croatia - Govor za Hrvatsku (1522.), Modruški zbornik: Posebna izdanja, knj. 1, I. Jurković - V. Moretti (eds.), Zagreb 2010.

FRANKAPAN 1518

Christopher Frankapan - Apollonia Lang - Jacob Wyg, Das deutsch-römisch Brevier..., ed. Gregorius de Gregoriis, Venice 1518.

FULIN 1890

Rinaldo Fulin et al. (eds.), I diarii di Marino Sanuto, vol. 29, Venice 1890.

GLIGO 1983

Vedran Gligo (ed.), Govori protiv Turaka - Orationes contra Turcas, ser. Humanisti, bk. 7, Split 1983.

HORÁNYI 2017

Károly Horányi - Edit Krähling (eds.), Calliotheca. Gems from the Library of the Hungarian Academy of Sciences, Budapest 2017.

HORVAT 2002

Zorislav Horvat, Sačuvani nadgrobni spomenici nekih Senjana i osoba značajnih za povijest Senja - u Senju i drugdje [The Gravestones of 
some Senians and some other Persons important for the History of Senj. Preserved at Senj and Elsewhere], Senjski zbornik, sv. 29, 2002, 47-86. HORVAT 2005

Zorislav Horvat, Pregled sačuvanih nadgrobnih ploča krčkih knezova Frankopana [Overview of the Preserved Gravestones of the Frankapan Counts of Krk], Senjski zbornik, vol. 32, 2005, 25-56.

\section{HORVÁTH 1964}

István K. Horváth (ed.), Orationes Ladislai de Macedonia, Acta Universitatis de Attila József nominatae, Acta antiqua et archaeologica, tom. VII, Szeged 1964.

\section{JURKOVIĆ 1999}

Ivan Jurković, Diplomatska aktivnost hrvatskoga plemstva u vrijeme turskoga pritiska na Hrvatsku [Diplomatic activity of Croatian nobility at the time of Ottoman pressure on Croatia], in M. Andrlić - M. Valentić (eds.), Hrvatska srednjovjekovna diplomacija [Croatian medieval diplomacy], Zbornik Diplomatske akademije, vol. 2, Zagreb 1999, 243-256.

\section{JURKOVIĆ 2017}

Ivan Jurković, O grbovima u molitvenicima koje su dali tiskati 1518 . u Veneciji Krsto Frankapan sa suprugom Apolonijom Lang i 1560. u Padovi Katarina Frankapan, supruga Nikole Zrinskog Sigetskog [On the Coats-of-Arms in the Prayer Books Printed in Venice in 1518 by Christopher Frankapan and His Wife Apolonia Lang and in Padua in 1560 by Catherina Frankapan, the Wife of Nicholas IV of Zrin (the Hero of Szigetvár)], Zbornik Odsjeka za povijesne znanosti Zavoda za povijesne $i$ društvene znanosti HAZU, vol. 35, 2017, 61-84.

JURKOVIĆ 2018

Ivan Jurković, Njemačko-rimski brevijar 1518. (500. obljetnica) [German-Roman Breviary 1518 (500th Anniversary)], Istarska danica, year 2018, Pazin 2017, 72-75.

JURKOVIĆ 2018

Ivan Jurković, Jedinstvo kultura sjevernog Jadrana [The unity of cultures of the Northern Adriatic], Jurina i Franina 2019: istarski kalendar, bk. $65,2018,48-49$.

\section{JURKOVIĆ 2019}

Ivan Jurković, Sveti Grgur Veliki u Njemačko-rimskom brevijaru (1518.), na freskama u Sveticama (1541.) i u Raju duše (1560.) koje su naručili Frankapani Modruški i Ozaljski [Gregory the Great in the German-Roman Breviary (1518), on frescoes in Svetice (1541) and in the Hortulus animae (1560) commisioned by the Frankapani of Modruš and Ozalj], Slovo: časopis Staroslavenskog instituta u Zagrebu, vol. 70, 2019, 137-154. 


\section{KLAIĆ 1901}

Vjekoslav Klaić, Krčki knezovi Frankapani. Knjiga prva. Od najstarijih vremena do gubitka otoka Krka (od god. 1118. do god. 1480.) [The Counts Frankapani of Krk. Book first. From the Earliest Times to the Loss of the Island of Krk (from 1118 to 1480)], Zagreb 1901.

KLAIĆ 1973

Vjekoslav Klaić, Povijest Hrvata [A History of the Croats], bk. 4, Zagreb 1973.

\section{КОМJÁTHI 1883}

Benedek Komjáthi, Epistolae Pavli lingva Hvngarica donatae. Az Zenth Paal leveley magyar nyelven (ed. Hieronymus Vietor in Krakow 1533), fasc. ed. with notes by Áron Szilády, Pest 1883.

\section{KRUHEK 2016}

Milan Kruhek, Modruški Bernardin i Krsto Frankopan: mačem i govorom za Hrvatsku [Bernardin and Krsto Frankapan of Modruš: with a sword and a speech for Croatia], Modruški zbornik, Posebna izdanja, vol. 3, Modruš 2016.

KUKULJEVIĆ SAKCINSKI 1885

Kukuljević Sakcinski, Ivan, Beatrica Frankopan i njezin rod [Beatrice Frankapan and her kinderd], Zagreb 1885.

\section{LOCKWOOD 2009}

Lewis Lockwood, Music in Renaissance Ferrara 1400-1505: The Creation of a Musical Center in the Fifteenth Century, New York - Oxford 2009.

LUCERNA 1925

Camilla Lucerna, Das Frankopani - Brevier, Der Morgen, Jg. 3, Nr. 687, Zagreb 1925, p. 12.

\section{LJUBIĆ 1880}

Šime Ljubić, Natpis Krsta Frankopana i njegove žene Apolonije, u Mletcih [The inscription of Christopher Frankapan and his wife Apollonia], Viestnik Hrvatskoga arkeologičkoga družtva II/1, 1880, 61-62.

\section{MARKOVIĆ 2006}

Predrag Marković, Mramorni reljefi venecijanske radionice Bon u Senju i krčki knezovi Frankopani [Marble Reliefs of the Venetian Workshop of Bon in Senj and the Family od Counts of Krk / the Frankapans], Radovi Instituta povijesti umjetnosti, vol. 30, 2006, 9-28.

\section{MESIĆ 1870}

Matija Mesić, Krsto Frankapan u tudjini [Christopher Frankapan in a foreign land], Rad Jugoslavenske akademije znanosti i umjetnosti, vol. 13, 1870, 17-79. 


\section{MESIĆ 1996}

Matija Mesić, Hrvati na izmaku srednjega vijeka [Croats at the close of the Middle Ages], Bibliotheca Croatica - Slavonica, Sirmiensia et Baranyensia, Pretisci, bk. 1, Slavonski Brod 1996.

MESIĆ 2000

Matija Mesić, Pleme Berislavića [The Berislavići kindred] (Rad JAZU, vol. 8, 1869, 30-104), fasc. ed. Slavonski Brod 2000.

\section{MOGUŠ 1995}

Milan Moguš - Josip Vončina - Franjo Emanuel Hoško, Raj Duše s motrišta našega vremena [Hortulus Animae from the perspective of our time], as a separate study of fasc. repr. of: Nikola Dešić, Raj duše, ed. by F. E. Hoško - M. Moguš - J. Vončina, Rijeka 1995.

\section{MORETTI 2009}

Violeta Moretti, Oratio pro Croatia Bernardina Frankapana [Bernardin Frankapan's Oratio pro Croatia], Modruški zbornik, vol. 3, 2009, 165-186.

\section{MOSEL 1835}

Ignaz Franz von Mosel, Geschichte der Kaiserl. Königl. Hofbibliothek zu Wien, Vienna 1835.

\section{NÉMETH 1993}

Katalin S. Németh, Ungarische Drucke und Hungarica 1480-1720, Teil 1-3, Munich-New York-London-Paris 1993.

\section{PANZERS 1788}

Georg Wolfgang Panzers, Annalen der ältern deutschen Litteratur..., Nürnberg 1788.

\section{PARDI 1934}

Giuseppe Pardi (ed.), Bernardino Zambotti, Diario ferrarese dall'anno 1409 sino al 1502, in Rerum Italicarum Scriptores, tom. XXIV, part. VII, fasc. 5-6, Bologna 1934.

PRIJATELJ PAVIČIĆ 1998

Ivana Prijatelj Pavičić, Kroz Marijin Ružičnjak: Zapadna marijanska ikonografija u dalmatinskome slikarstvu od 14. do 18. st. [Through Mary's Rose Garden: Western Marian Iconography in the Dalmatian Paintings from the Fourteenth to Eighteenth Centuries], Split 1998.

PUGLIA 2005

Ilaria Puglia, I Piccolomini d'Aragona duchi di Amalfi (1461-1610). Storia di un patrimonio nobiliare, ser. Ricerche storiche 9, Naples 2005.

RAUKAR 1997

Tomislav Raukar, Hrvatsko srednjovjekovlje: Prostor, ljudi, ideje [The Croatian Middle Ages. Territory, people, ideas], Zagreb 1997. 


\section{SALETTI 2015}

Beatrice Saletti, La successione di Leonello d'Este e altri studi sul Quattrocento ferrarese, Collana: Studi e progetti, Padua 2015.

\section{SETTON 1978}

Kenneth M. Setton, The Papacy and the Levant, 1204-1571. The fifteenth century, Philadelphia 1978.

SMIČIKLAS 1882

Tadija Smičiklas, Poviest hrvatska [Croatian history], Zagreb 1882.

SRDOČ-KONESTRA 2018

Ines Srdoč-Konestra - Saša Potočnjak (eds.), Putovima Frankopana [The routes of the Frankopans], Rijeka 2018 (online edition:

https://bib.irb.hr/datoteka/987418.Putovima-Frankopana.pdf)

\section{STRČIĆ 1998}

Petar Strčić, Frankapan, Krsto I. Brinjski, in Hrvatski biografski leksikon [Croatian biographical lexicon], vol. 4, Zagreb 1998, p. 414.

\section{ŚWIERK 1976}

Alfred Świerk, Hieronymus Vietor (Wietor) - ein Pionier des polnischen Buchdrucks im 16. Jahrhundert, Gutenberg-Jahrbuch, Jahr. 51, 1976, 194-199.

\section{ŠERCER 2011}

Marija Šercer, Žene Frankopanke [The Frankapani women], Modruški zbornik, vol. 4-5, 2011, 21-81.

ŠPOLJARIĆ 2016

Luka Špoljarić, Illyrian Trojans in a Turkish Storm: Croatian Renaissance Lords and the Politics of Dynastic Origin Myths, in P. Baker R. Kaiser - M. Priesterjahn - J. Helmarth (eds.), Portraying the Prince in the Renaissance. The Humanist Depiction of Rulers in Historiographical and Biographical Texts, ser. Transformationen der Antike, vol. 44, Berlin 2016, 121-156.

\section{THODE 1992}

Henry Thode, Der Ring des Frangipani: ein Erlebniss, Frankfurt am Main 1895; idem, Frangipani's Ring. An Event in the Life of Henry Thode, London 1900 and 1904; idem, Frankopanov prsten: doživljaj, Zagreb 1944 and 1992.

TUOHY 2002

Thomas Tuohy, Herculean Ferrara: Ercole D'Este (1471-1505) and the Invention of a Ducal Capital, Cambridge 2002.

VAJAY 1999

Szabolcs de Vajay, Un ambassadeur bien choisi: Bernardinus de Frangipanus et sa mission à Naples, en 1476, in B. Nagy - M. Sebók (eds.), 
The Man of Many Devices, Who Wandered Full Many Ways: Festschrift in Honor of János M. Bak, Budapest 1999, 550-557.

VERSTEGEN 2007

Ian F. Verstegen (ed.), Patronage and Dynasty: the Rise of the Della Rovere in Renaissance Italy, ser. Sixteenth Century Essays \& Studies, vol. 77, Kirksville 2007.

\section{ZAZZERA D'ARAGONIA 1617}

Francesco Zazzera d'Aragonia, Della famiglia Frangipani tratta della seconda parte della nobiltà dell'Italia, Naples 1617.

ZEČEVIĆ 2014

Nada Zečević, The Tocco of the Greek Realm: Nobility, Power and Migration in Latin Greece (14th - 15th centuries), Beograd - Istočno Sarajevo 2014.

\section{ŽIC 1933}

Nikola Žic, Brevir Krsta Frankopana [Breviary of Christopher Frankapan], Obzor 74/224, Zagreb 1933, 2-3. 


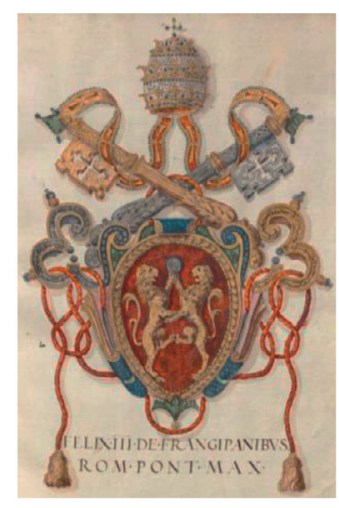

a

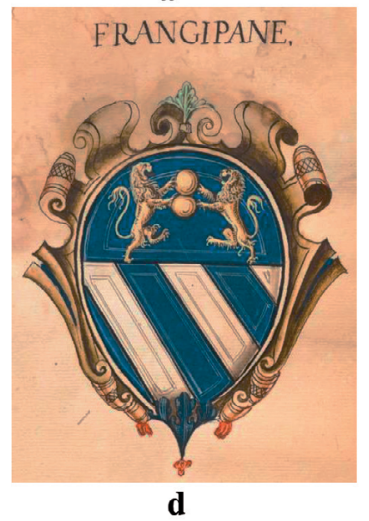

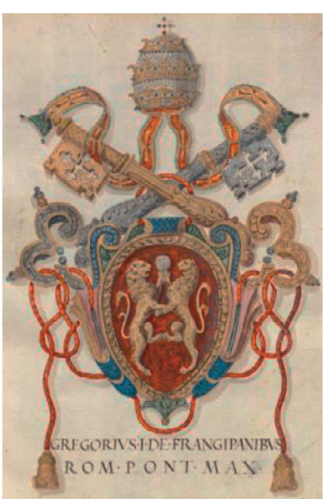

b

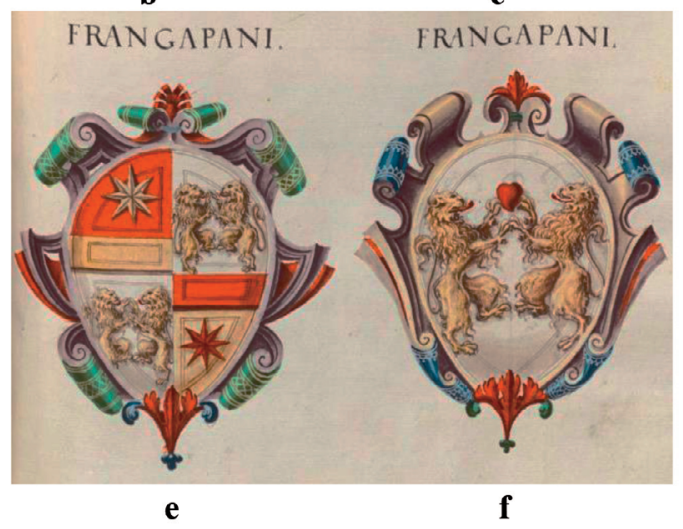

Fig. 1. The Frankapani coats of arms

a) Pope Felix III (BSB, Cod.icon. 266 [Katalog], fol. 1r)

b) Pope Gregory I (BSB, Cod.icon. 266 [Katalog], fol. 2r)

c) the Frankapani of Rome (BSB, Cod.icon. 268 [Katalog], fol. 59r)

d) the Frankapani of Naples (BSB, Cod.icon. 279 [Katalog], fol. 49r)

e) the Frankapani of Krk, Senj, and Modruš (BSB,

Cod.icon. 272 [Katalog], fol.161r)

f) the Frankapani of Venice (BSB, Cod.icon. 272 [Katalog], fol. 161r) 
The FRANKAPANI

of KRK, SENJ, and MODRUŠ

of CETIN and RMANJ

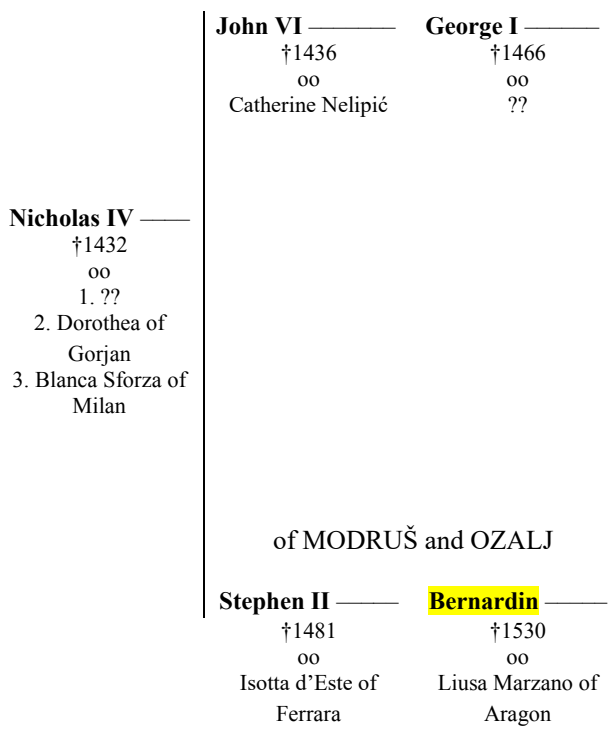

Fig. 2. The Frankapani genealogy Nicholas IV had eight sons - here are the descendants of two of his sons mentioned in the article

Mary Branković
John XII

$\dagger 1543$

Archbishop of

Kalocsa

John X

$\dagger 1493$

oo

Dorothea

Andrew

$\dagger 1499$

Nicholas VIII $\dagger 1481$

Gregory I $\dagger 1520$

Archbishop of Kalocsa

Dorothea $\dagger 1504$ oo John of Blagaj

\section{Matthias} $\dagger 1518$ oo

Sophia Thuz de Lak

Christopher $\dagger 1527$ oo

Apollonia Lang

John XI

Bishop of Modruš

$\uparrow c .1525$

Stephen III

Beatrice

$\uparrow 1510$

1. John Corvinus

2. George of

Brandenburg

Mary Magdalen

betrothed to

Matthias Pongrácz

Isotta

$\dagger 1545$

oo

1. Ladislaus

Egerváry

2. Stephen Perényi

3. Caspar Serédy
Catherine

$\uparrow 1540$

Gabriel Perényi
Catherine

$\uparrow 1562$

Nicholas Zrinski 

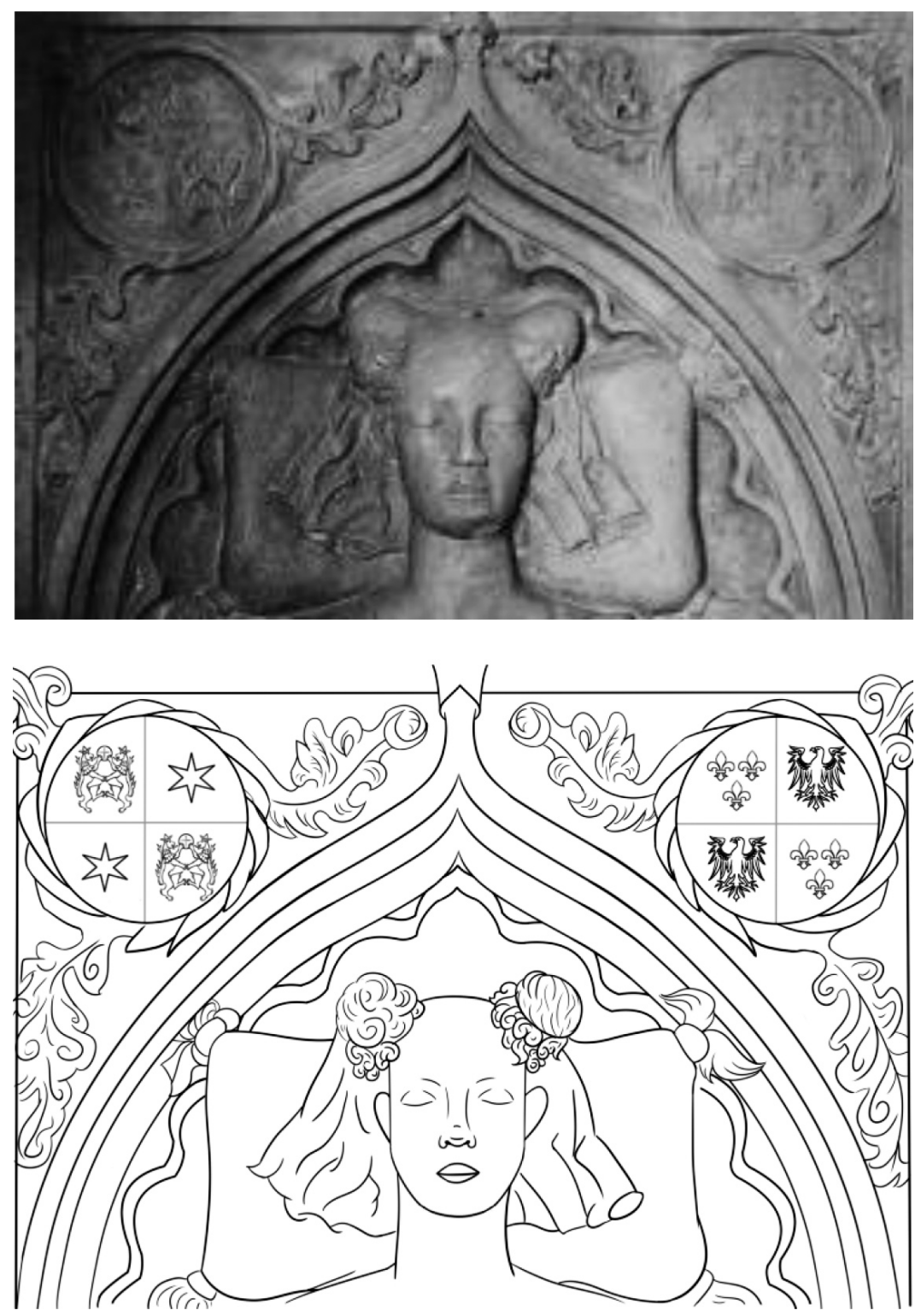

Fig. 3. The upper part of Isotta's tombstone (image taken from: Vjekoslav Klaić, Krčki knezovi Frankapani..., p. 242; copied and the coats of arms reconstructed by Iva Jurković) 


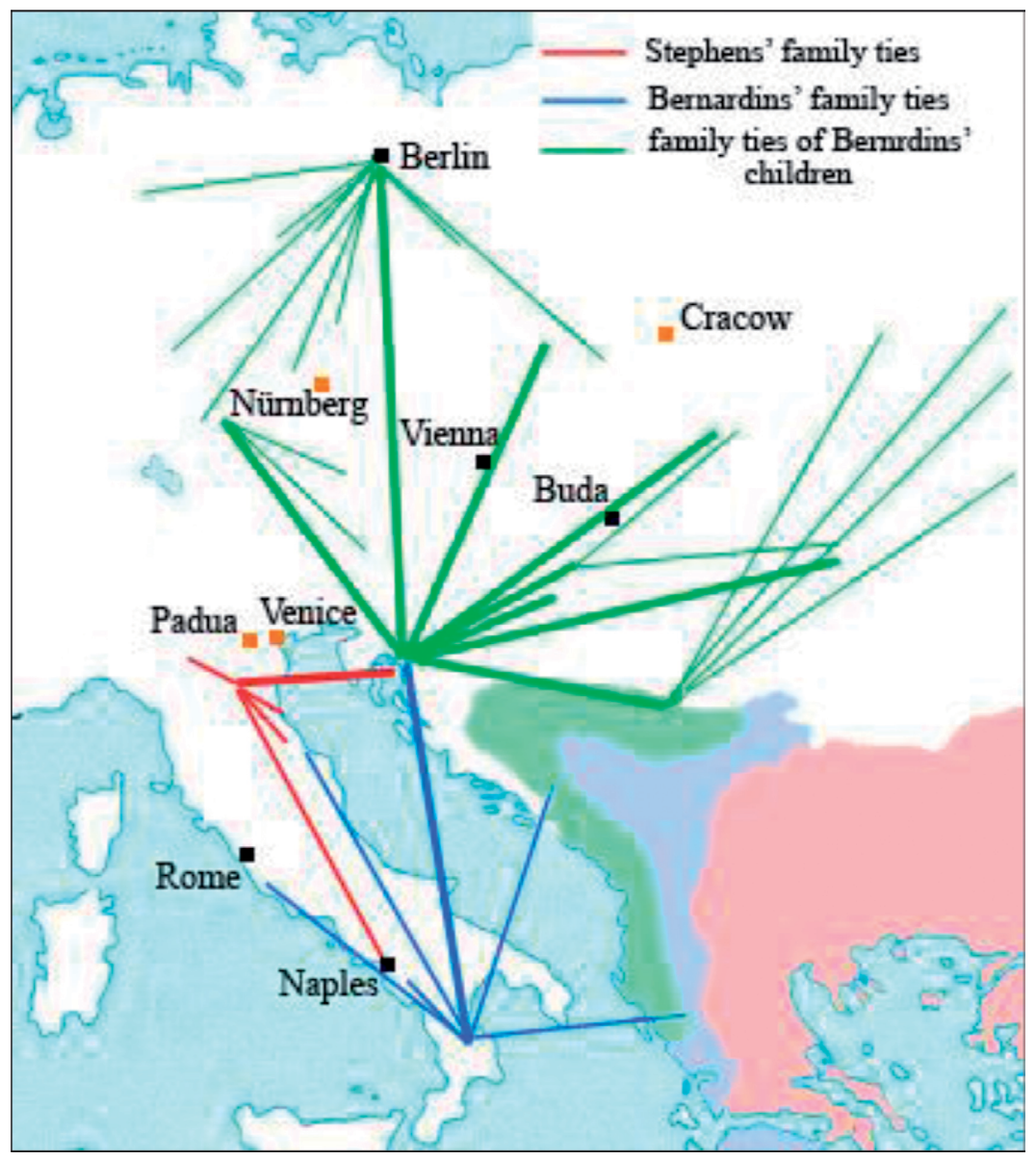

Fig. 4. The Frankapani of Modruš and Ozalj network offamily/kin ties 


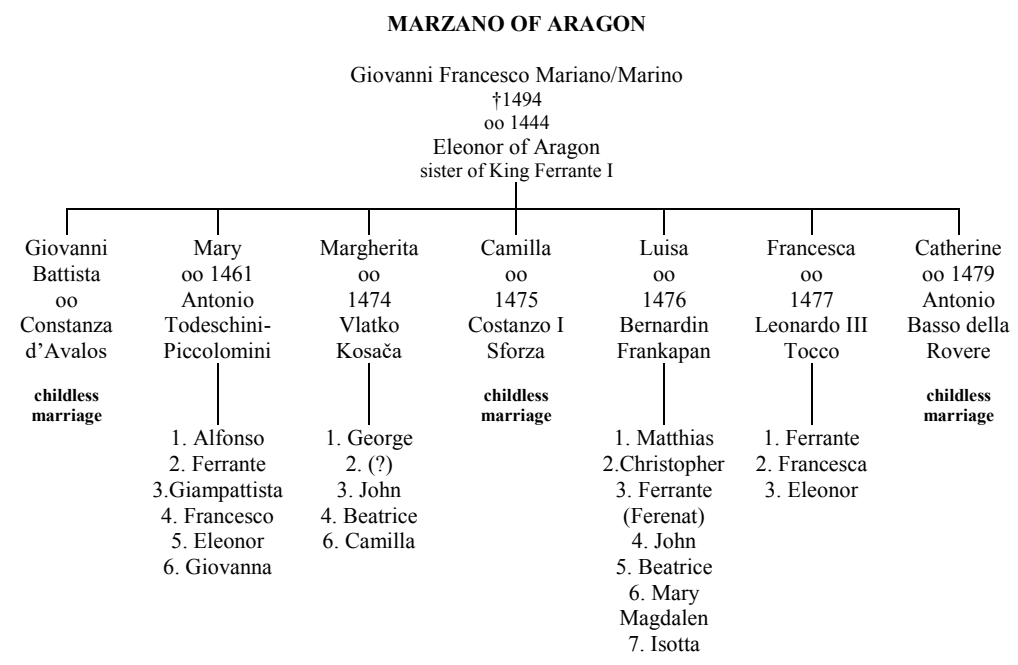

Fig. 5. Mariano's children and their marriages arranged by King Ferrante I 

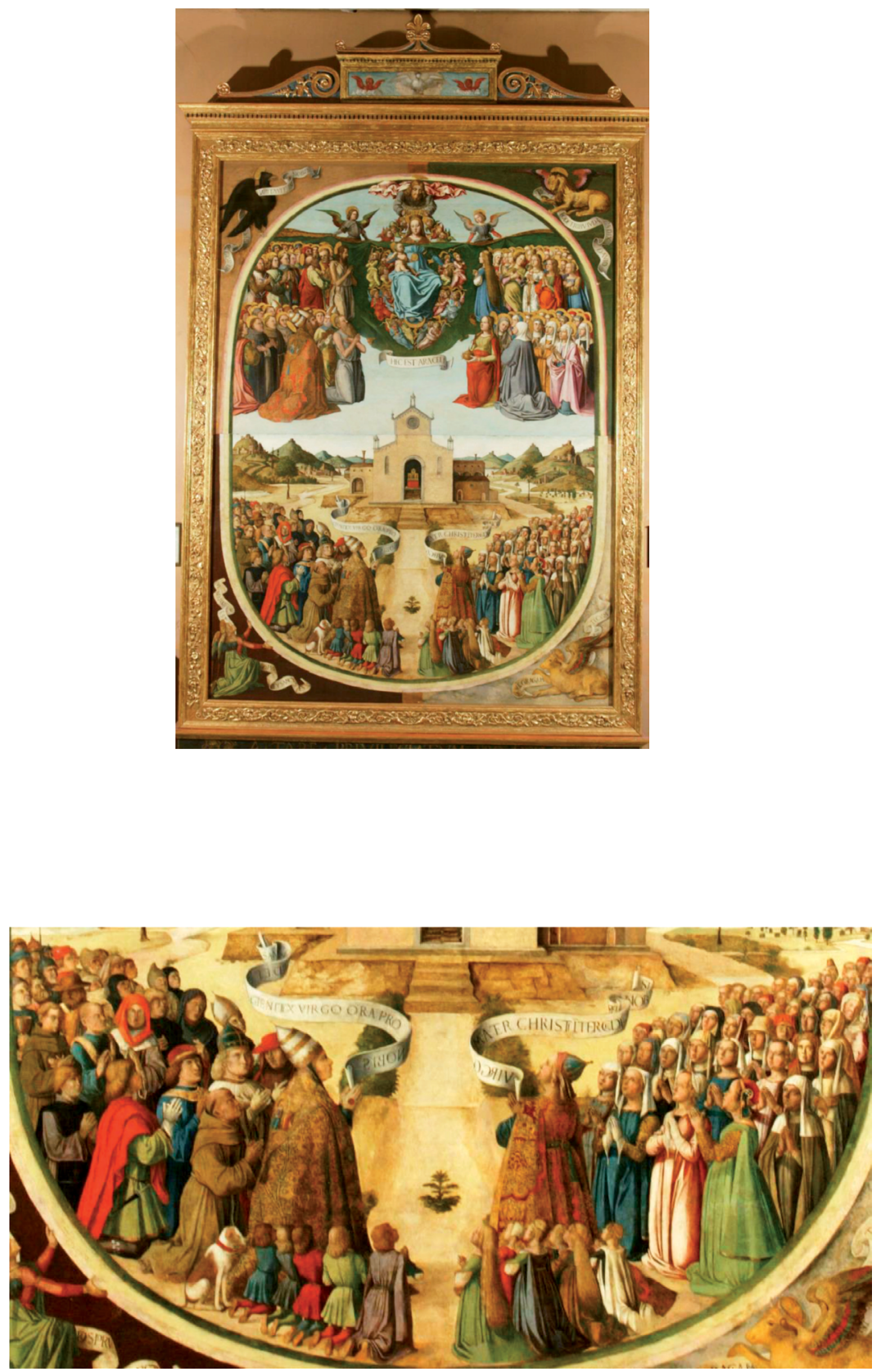

Fig. 6. Our Lady of Mercy - Lazzaro Bastiani (?) in Monastery of St. Francis of Assisi in Zadar 


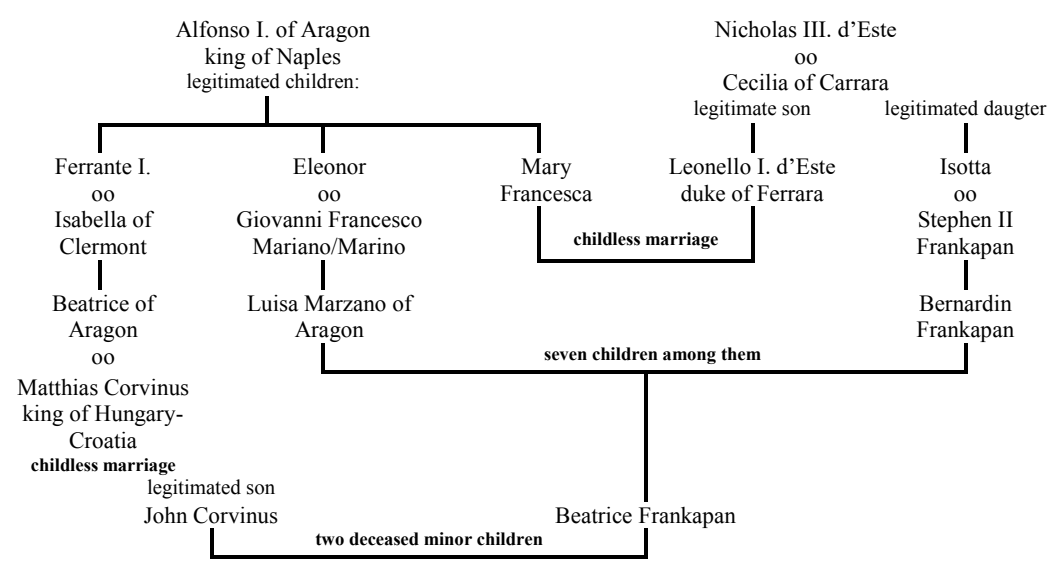

Fig. 7. Dynastic ties of the Frankapanifamily

(Cf. Szabolcs de Vajay, „Un ambassadeur bien choisi...,” p. 557, fig. 1 and 2)

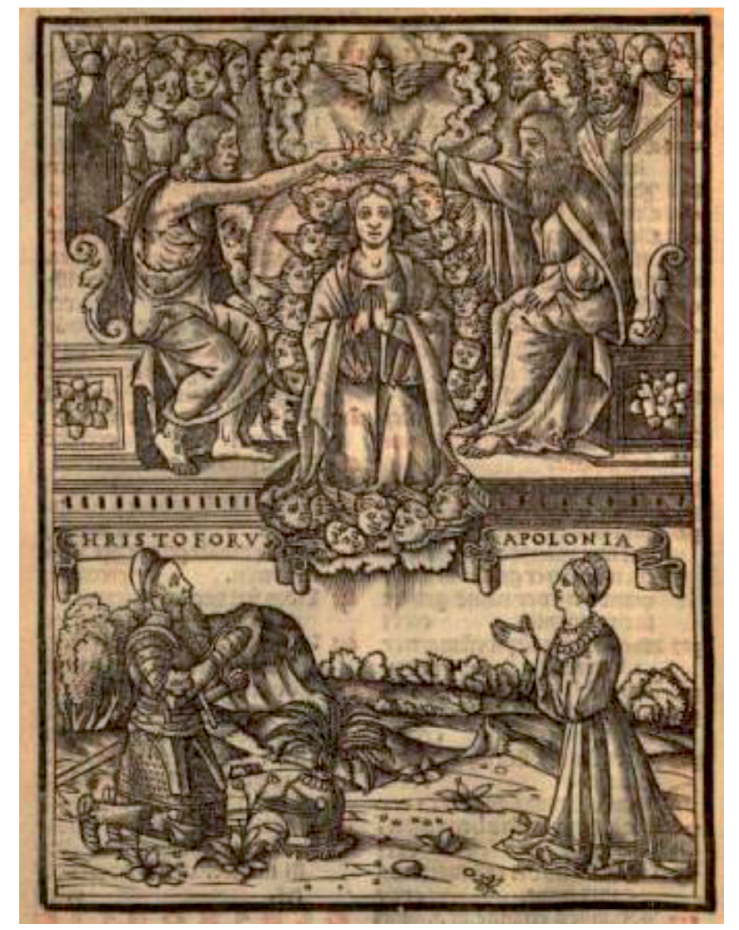

Fig. 8. „The coronation of the Virgin” with Christopher and Apollonia on their knees

in Das deutsch-römisch Brevier, Venice: Gregorio de Gregoriis, October 31, 1518. 


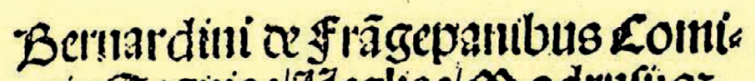

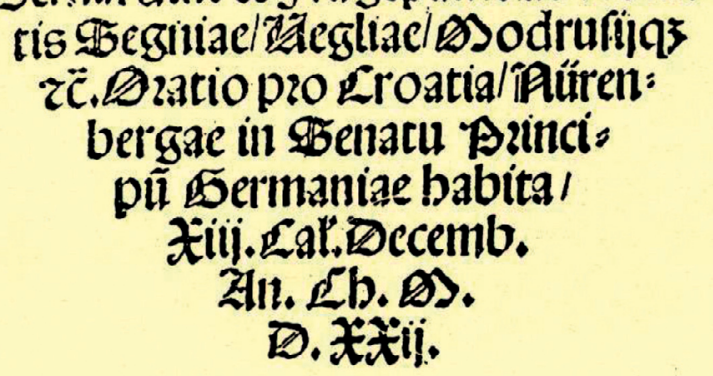

\section{Excidium veluti TRomanae aßsaximus vibi}

Zucrtit Ie atriaefic tuga orra Romes.

R. Sbruliug.

Fig. 9. Bernardini de Frangepanibus (...) Oratio pro Croatia

Nuremberg: Friedrich Peypus, 1522. 


\section{EPISTOLÆ}

\section{PAVLI LINGVA HVN GARICA DONATAE.}

\section{AZ ZENTH PAAL leueley magyar nyeituen.}

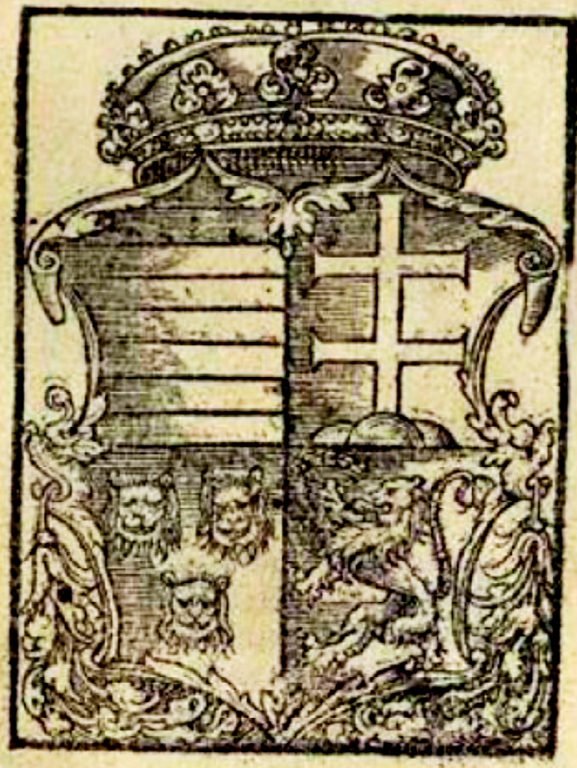

Fig. 10. Epistolae Pavli lingva Hvngarica donatae. Az Zenth Paal leueley magyar nyeluen Krakow: Hieronymus Vietor, 1533. 


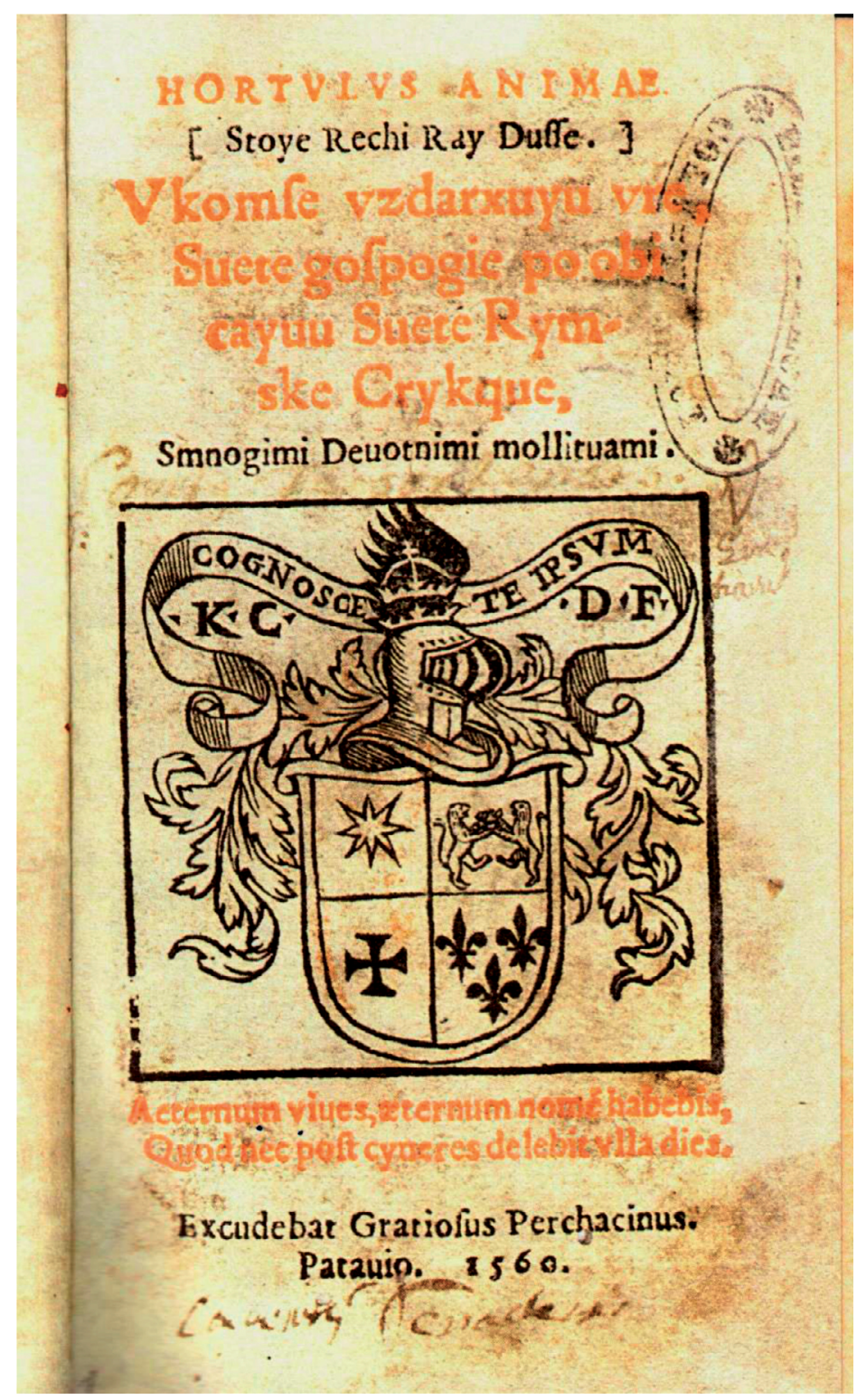

Fig. 11. Hortvlvs Animae [Stoye Rechi Ray Dusse]... Padua: Gratiosus Perchacinus, 1560. 


\section{SUMMARY}

\section{Family Ties and Written Multilingual Heritage of the Frankapani at the Dawn of the Early Modern Period}

In the second half of the fifteenth and the first half of the sixteenth century the Frankapani of Krk, Senj, and Modruš were at the peak of their power. This family of Croatian counts was networked through marriage from the Adriatic to the Baltic Sea with Italian, Hungarian, Austrian, and German royal and aristocratic families. Their presence in the courts of their next of kin, as well as their in-laws, is therefore not surprising, whether it be the Roman Curia or the Hohenzollern Branderburger Palace in Berlin. In such a wide system of communications, the Frankapani presented themselves to the European public as a multilingual family ready to promulgate not only the written heritage nurtured during the Middle Ages in Croatia (Latin and Glagolitic), but also ready to adopt, promote, and disseminate the written heritage of their spouses (Italian, German, Hungarian). The following examples attest to this statement: the Roman breviary translated into the German language by Christopher Frankapan and his wife Apollonia Lang printed in 1518 in Venice, the anti-Turkish speech in Latin delivered by Christopher's father, Bernardin, before the German assembly in Nuremberg and printed in $\mathbf{1 5 2 2}$ for the occasion, the translated epistles of Saint Paul, from Latin to Hungarian, donated by Catherine Frankapan married to Gabriel (Gábor) Perényi, printed in Krakow in 1533, and the first Croatian-language breviary written in the Latin script, rather than in the Glagolitic, commissioned by Catherine Frankapan married to Nicholas Zrinski, published in 1560 in Padua. 


\section{SAŽETAK}

Obiteljske veze i pisana višejezična baština Frankapana u osvit ranoga novog vijeka

Druga je polovica 15. i prva polovica 16 . stoljeća razdoblje vrhunca moći Frankapana Krčkih, Senjskih i Modruških. Ta je hrvatska grofovska obitelj bračnim vezama bila umrežena od Jadrana do Baltika s talijanskim, ugarskim, austrijskim i njemačkim vladarskim i velikaškim obiteljima. Ne čudi stoga njihova nazočnost na dvorovima moćnika koji su im bili u prvom koljenu srodstva, ali isto tako i na dvorovima zajedničke im svojte, počevši od Rimske kurije pa do dvora Hohenzollerna Brandenburških u Berlinu. U takvom se širokom sustavu veza Frankapani predstavljaju europskoj javnosti kao multilingvalna obitelj spremna na širenje ne samo pisane baštine njegovane tijekom srednjeg vijeka u Hrvatskoj (latinske i glagoljaške), već i na usvajanje, promoviranje i širenje pisane baštine svojih supružnika (talijanske, njemačke, mađarske). Tomu svjedoče primjerice Rimski brevijar preveden na njemački jezik Krste Frankapana i supruge mu Apolonije Lang otisnut 1518. god. u Veneciji, protuturski govor na latinskom jeziku Krstina oca Bernardina pred njemačkim staležima otisnut 1522. god. u Nürnbergu, doniranje prijevoda s latinskoga na mađarski jezik poslanica sv. Pavla Katarine Frankapan udane za Gabrijela (Gábora) Perényija, koji je i tiskan u Krakovu 1533. god. te prvi časoslov otisnut latiničkim, a ne glagoljskim slovima na hrvatskom jeziku Katarine Frankapan udane za Nikolu Zrinskog, objavljen 1560. god. u Padovi.

Ključne riječi: Frankapani Krčki, Senjski i Modruški, Rimski brevijar, protuturski govor Oratio pro Croatia, prijevod poslanica sv. Pavla Epistolae Pavli lingva Hvngarica donatae, molitvenik Hortulus Animae, simbolička komunikacija, (samo)promocija, šesnaesto stoljeće 